\title{
Friction Modifiers Optimization on Tribological Properties of Non-asbestos Organic (NAO) Brake Pad by DoE-Taguchi Method
}

\author{
Jamasria, H.S.B. Rochardjo ${ }^{a}$ P. Nawangsaria,*, A.T. Waskito ${ }^{b}$ \\ a Mechanical and Industrial Engineering Department, Universitas Gadjah Mada, Jl. Grafika No.2, Yogyakarta 55281, \\ Indonesia, \\ bIndo Bintang Mandiri, Delta Silicon 3, Jl. Soka Blok F-20 No. 8B-5, Cikarang Pusat, Bekasi, Indonesia.
}

Keywords:

\section{Friction modifier}

Taguchi Method

ANOVA

$S / N$ ratio

CoF stability

Wear

* Corresponding author:

Putri Nawangsari

E-mail:

putri.nawangsari@mail.ugm.ac.id

Received: 27 January 2021

Revised: 11 March 2021

Accepted: 27 April 2021

\begin{abstract}
A B S T R A C T
Friction modifiers play an important role in modifying the friction performances on the brake pad material. This study aims to determine the optimal friction modifier composition for obtaining a high friction coefficient (CoF) stability and low wear with the Taguchi method. Taguchi's L8 orthogonal array consists of five factors, and two levels were used to design and perform the experiment. The tribological properties (CoF stability and wear) were tested using the JF160 Chase friction tester according to the SAE J661 standard. According to the S/N ratio and ANOVA analysis, the controllable factor of $h-B N$ has a significant effect on CoF stability. While graphite and $h-B N$ have a dominant influence on wear. Contribution of 4 vol. \% h-BN, 4 vol.\% $\mathrm{MoS}_{2}, 4$ vol. $\% \mathrm{Al}_{2} \mathrm{O}_{3}, 2$ vol.\% graphite, and 3 vol.\% $\mathrm{SiO}_{2}$ is an optimal composition to obtain high CoF stability. Meanwhile, the contribution of graphite (8 vol.\%), h-BN (2 vol.\%), MoS2 (4 vol.\%), $\mathrm{Al}_{2} \mathrm{O}_{3}$ (2 vol.\%), and $\mathrm{SiO}_{2}$ (3 vol.\%) can be an optimal composition on lower wear. The predictive value of CoF stability and wear on the optimal level, as made by the Taguchi method, is consistent with the confirmation test within a 95\% confidence interval (CI).
\end{abstract}

(C) 2021 Published by Faculty of Engineering

\section{INTRODUCTION}

The brake pad materials usually comprise more than 10-20 different ingredients [1-2], which are grouped as binders, reinforcements, fillers, and friction modifiers [3-7]. Friction modifiers are one of the brake pad ingredients that play an important role in modifying friction and wear performances as they serve both as abrasives and solid lubricants.
Abrasives increase friction and wear rate. Abrasives usually are added around 1-8 vol.\% to the brake pad [9]. High content of abrasives in the brake pad materials causes instability of friction coefficient, damage to the disc, and noise during the braking [10]. On the contrary, solid lubricants are beneficial to reduce abrasion between pad and disc, improve wear resistance, dampen vibration, and decrease noise [8]. Hence, a careful selection of the 
composition between abrasives and solid lubricants is crucial since they often have the opposite effect on the friction performances generated during the braking.

There are commonly used materials as abrasives and solid lubricants in the brake pad. The abrasive materials are silicon carbide ( $\mathrm{SiC}$ ), zirconium oxide $\left(\mathrm{ZrO}_{2}\right)$, zirconium silicate $\left(\mathrm{ZrSiO}_{4}\right)$, aluminum oxide $\left(\mathrm{Al}_{2} \mathrm{O}_{3}\right)$, and silicon dioxide $\left(\mathrm{SiO}_{2}\right)$ [11]. Meanwhile, antimony sulfide $\left(\mathrm{Sb}_{2} \mathrm{~S}_{3}\right)$, graphite, copper sulfide (CuS), hexagonal boron nitride (h-BN), and molybdenum disulfide $\left(\mathrm{MoS}_{2}\right)$ are frequently used as solid lubricants in the brake pad [12].

In previous studies, materials such as $\mathrm{ZrSiO}_{4}$ [13], $\mathrm{Al}_{2} \mathrm{O}_{3}$ [14-16], $\mathrm{SiO}_{2}$ [17], $\mathrm{SiC}$ [13], h-BN $[18,19], \mathrm{Sb}_{2} \mathrm{~S}_{3}[20], \mathrm{MoS}_{2}$ [21], and graphite [22] have been studied. These studies only focused on understanding the individual effects of abrasives and solid lubricants on the brake friction performances experimentally. However, no comprehensive study ever discussed statistically and experimentally between abrasives and solid lubricants (friction modifiers) on brake friction performances with the Taguchi method.

Selection of the proper friction modifier composition is necessary because it directly affects brake friction performances. The availability of a significant number of the friction modifiers compositions has a complex relationship with the braking results. Consequently, composition selection is a difficult task and requires a great number of experiments. Taguchi method can be used to reduce the number of experiments efficiently [23-25]. This study aims to determine the optimal friction modifier composition (namely: $\mathrm{Al}_{2} \mathrm{O}_{3}, \mathrm{SiO}_{2}, \mathrm{MoS}_{2}$, h-BN, and graphite) to obtain high CoF stability and low wear using Taguchi Method.

\section{EXPERIMENTAL}

\subsection{Design of experiment (DOE)}

Taguchi's design was applied to design an optimum level of friction modifiers for maintaining the variance at high CoF stability and low wear. In the present study, five controllable factors of friction modifier materials (graphite, hexagonal boron nitride (h-BN), molybdenum disulfide $\left(\mathrm{MoS}_{2}\right)$, aluminum oxide $\left(\mathrm{Al}_{2} \mathrm{O}_{3}\right)$, and silicon dioxide $\left.\left(\mathrm{SiO}_{2}\right)\right)$ and two levels for each of these factors were selected with Taguchi design, as shown in Table 1. According to the optimal value reported in the article published on the brake friction performance, the levels of each factor were selected. Taguchi $\mathrm{L}_{8}$ (23) orthogonal array with eight number of experiments was selected to experiment. Furthermore, the experimental results were analyzed using the statistical software MINITAB 17. The $\mathrm{S} / \mathrm{N}$ ratio is determined from the experimentally observed value and then statistically analyzed by ANOVA (Analysis of Variance). Table 2 shows the experimental layout of the Taguchi $\mathrm{L}_{8}$ orthogonal arrays.

Table 1. Experimental factors and their levels.

\begin{tabular}{|c|c|c|}
\hline \multirow{2}{*}{ Factor } & \multicolumn{2}{|c|}{ Level (vol.\%) } \\
\cline { 2 - 3 } & $\mathbf{1}$ & $\mathbf{2}$ \\
\hline Graphite & 4 & 8 \\
\hline $\mathrm{h}-\mathrm{BN}$ & 2 & 4 \\
\hline $\mathrm{MoS}_{2}$ & 2 & 4 \\
\hline $\mathrm{Al}_{2} \mathrm{O}_{3}$ & 2 & 4 \\
\hline $\mathrm{SiO}_{2}$ & 3 & 5 \\
\hline
\end{tabular}

Table 2. Experimental layout of Taguchi $\mathrm{L}_{8}\left(2^{3}\right)$ orthogonal array and results for two levels of parameter.

\begin{tabular}{|c|c|c|c|c|c|c|c|c|c|}
\hline \multirow{2}{*}{$\begin{array}{c}\text { Exp. } \\
\text { No }\end{array}$} & \multicolumn{4}{|c|}{ Control Factor (vol.\%) } & \multicolumn{5}{c|}{ Output Results } \\
\cline { 2 - 11 } & Graphite & h-BN & $\mathbf{M o S}_{\mathbf{2}}$ & $\mathbf{A l}_{\mathbf{2}} \mathbf{O}_{\mathbf{3}}$ & $\mathbf{S i O}_{\mathbf{2}}$ & CoF stability & $\begin{array}{c}\text { S/N ratio (dB) } \\
\text { for CoF stability }\end{array}$ & $\begin{array}{c}\text { Wear } \\
\text { (\%) }\end{array}$ & $\begin{array}{c}\text { S/N ratio (dB) } \\
\text { for wear }\end{array}$ \\
\hline 1 & 4 & 2 & 2 & 2 & 3 & 79.06 & 37.95 & 10.05 & -20.07 \\
\hline 2 & 4 & 2 & 2 & 4 & 5 & 77.46 & 37.78 & 8.02 & -18.08 \\
\hline 3 & 4 & 4 & 4 & 2 & 3 & 84.12 & 38.49 & 9.70 & -19.74 \\
\hline 4 & 4 & 4 & 4 & 4 & 5 & 89.30 & 39.02 & 15.91 & -24.03 \\
\hline 5 & 8 & 2 & 4 & 2 & 5 & 77.74 & 37.81 & 5.84 & -15.27 \\
\hline 6 & 8 & 2 & 4 & 4 & 3 & 81.56 & 38.23 & 5.52 & -14.81 \\
\hline 7 & 8 & 4 & 2 & 2 & 5 & 84.04 & 38.49 & 9.90 & -19.91 \\
\hline 8 & 8 & 4 & 2 & 4 & 3 & 83.99 & 38.48 & 8.73 & -18.79 \\
\hline
\end{tabular}


The brake pad sample was also comprised of binder (i.e., phenolic resin), fillers (i.e., friction dust and $\mathrm{BaSO}_{4}$ ), reinforcements (i.e., rockwool, cellulose, and PAN fibers), and copper. These ingredients were kept constant (78\% vol.\%), and $\mathrm{MgO}$ was varied in volume fraction to balance the total composition of the sample. The Taguchi design was used with the assumption that there was no interaction effect among other ingredients on tribological properties, and the composition $\mathrm{MgO}$ did not affect tribological properties.

\subsection{Sample preparation and tribological test}

The samples were manufactured with a fivestep process: weighing, mixing, hot pressing, post-curing, and finishing. The manufacturing details of the sample were explained in our previous study [26-27]. Tribological testing of the sample was carried out using the JF160 chase friction tester by following SAE J661 standard procedures. The test sample with a dimension of $25.4 \times 25.4 \times 7 \mathrm{~mm}$ (Fig. 1) was positioned on $140 \mathrm{~mm}$ an inner radius of friction drum. The sample was then pressed hydraulically against the friction drum under a normal load of $660 \mathrm{~N}$. The rotating speed of the friction drum was $411 \mathrm{rpm}$, and the linear sliding velocity of the sample was $6.028 \mathrm{~m} / \mathrm{sec}$. The schematic of the JF160 chase friction tester is given in Fig. 2. Each sample has followed seven stages of the testing procedure, as shown in Table 3. The tribological test was repeated three times for each sample parameter. Samples were then weighed, and their thickness was measured before and after the test. After test procedures were completed, $\mathrm{CoF}$ stability and wear were then calculated and taken as a response for performance optimization. CoF stability and wear were calculated using the following equations:

$$
\begin{aligned}
& \text { CoF stability }=\frac{\mu_{p}}{\mu_{\max }} \\
& W=\frac{w_{o}-w_{1}}{w_{o}} \times 100 \%
\end{aligned}
$$

Where $\mu_{\max }$ is a maximum friction coefficient, $\mu_{\mathrm{p}}$ is the average friction coefficient, $\mathrm{w}_{\mathrm{o}}$ and $\mathrm{w}_{1}$ are the average weight loss of the sample before and after the friction test.
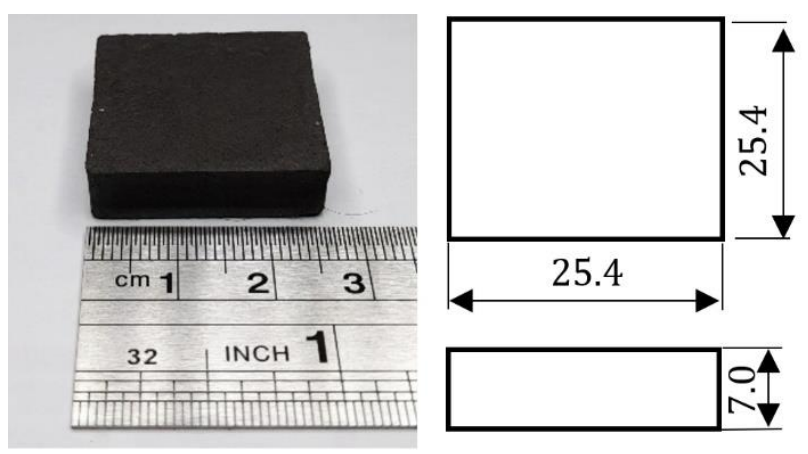

Fig. 1. Friction test sample.

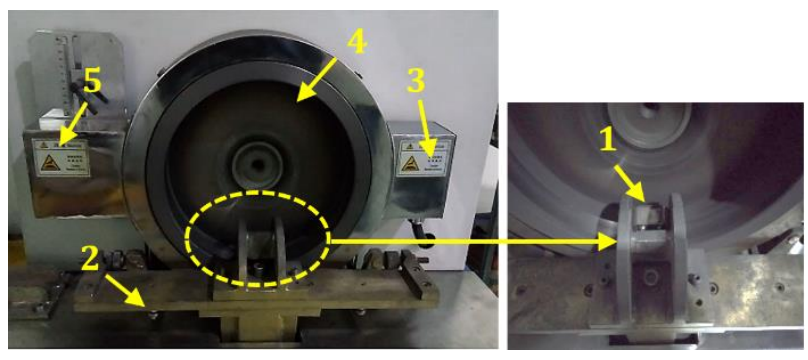

Fig. 2. JF160 chase friction tester: (1) sample, (2) loading arm, (3) blower, (4) friction drum, and (5) heater.

Table 3. Experimental procedure of SAE J661.

\begin{tabular}{|c|c|c|c|c|}
\hline Cycles & Load (N) & $\begin{array}{c}\text { Speed } \\
\mathbf{( r p m )}\end{array}$ & $\begin{array}{c}\text { Temperature } \\
\left({ }^{\circ} \mathbf{C}\right)\end{array}$ & Braking Mode \\
\hline Burnish & 440 & 312 & $<95$ & Continues braking for 20 min \\
\hline Initial baseline & 660 & 411 & $82-104$ & Intermittent braking 10 sec On, 20 sec Off for 20 applications \\
\hline Fade-I & 660 & 411 & $93-261$ & Continues and heater On \\
\hline Recovery-I & 660 & 411 & $260-92$ & Continues and blower On \\
\hline Wear & 660 & 411 & $193-204$ & Intermittent braking 10 sec On, 20 sec Off for 100 \\
\hline Fade-II & 660 & 411 & $93-345$ & Continues and heater On \\
\hline Recovery-II & 660 & 411 & $316-92$ & Continues and blower On \\
\hline Final baseline & 660 & 411 & $104-82$ & Intermittent braking 10 sec On, 20 sec Off for 20 applications \\
\hline
\end{tabular}




\section{RESULTS AND DISCUSSION}

\subsection{The S/N ratio and ANOVA for CoF stability}

Based on the Taguchi method, response variation using the $\mathrm{S} / \mathrm{N}$ ratio is crucial because it can minimize variations in quality characteristics due to uncontrollable parameters. CoF stability level must be as high as possible in the brake pad materials as it contributes to smooth braking and avoids jerks during braking applied [27]. Therefore, CoF stability response was considered a quality characteristic using the $\mathrm{S} / \mathrm{N}$ ratio " the large the better". The $\mathrm{S} / \mathrm{N}$ ratio of the quality characteristics "the large the better" is calculated by equation (3) [23].

$$
\frac{S}{N} \text { ratio }=-10 \log \left(\frac{1}{n} \sum_{i=1}^{n} \frac{1}{y_{i}{ }^{2}}\right)
$$

Where $y_{i}=$ experimental results, and $n=$ number of experiments. The average values of $\mathrm{CoF}$ stability measured from the experiment test and their S/N ratio are presented in Table 2 . Meanwhile, Table 4 shows the $\mathrm{S} / \mathrm{N}$ ratio of $\mathrm{CoF}$ stability for friction modifiers. According to the rank order, h-BN is the most influential, followed by $\mathrm{MoS}_{2}$ and $\mathrm{Al}_{2} \mathrm{O}_{3}$. In contrast, graphite and $\mathrm{SiO}_{2}$ are affected CoF stability the least.

Table 4. Responsible table for $\mathrm{S} / \mathrm{N}$ ratio of $\mathrm{CoF}$ stability of friction modifiers (the large the better).

\begin{tabular}{|c|c|c|c|c|c|}
\hline Level & Graphite & $\mathbf{h}-\mathbf{B N}$ & $\mathbf{M o S}_{\mathbf{2}}$ & $\mathbf{A l}_{\mathbf{2}} \mathbf{O}_{\mathbf{3}}$ & $\mathbf{S i O}_{\mathbf{2}}$ \\
\hline 1 & 38.31 & 37.95 & 38.18 & 38.19 & 38.29 \\
\hline 2 & 38,25 & 38.62 & 38.39 & 38.38 & 38.27 \\
\hline Delta & 0.06 & 0.68 & 0.21 & 0.19 & 0.02 \\
\hline Rank & 4 & 1 & 2 & 3 & 5 \\
\hline
\end{tabular}

Fig. 3 reveals the main effect plot for the $\mathrm{S} / \mathrm{N}$ ratio of CoF stability. In the main effect plot, if the line for a certain factor is near horizontal, the factor has no significant effect on the response. On the contrary, the factor with the highest slope of the line has the most considerable effect. As presented in Fig. 3, the optimal CoF stability for the vol.\% contribution is obtained on 4 vol.\% graphite, 4 vol. $\%$ h-BN, 4 vol. $\% \mathrm{MoS}_{2}, 4$ vol.\% $\mathrm{Al}_{2} \mathrm{O}_{3}$, and 3 vol.\% $\mathrm{SiO}_{2}$. The controllable factor of h-BN significantly affects on CoF stability because $\mathrm{h}$-BN is a good lubricant at elevated temperature, improving heat resistance, and lubrication ability on the friction material [29]. Yanar et al. [30] reported that the h-BN composition of 2.5 to 3 vol.\% in non-asbestos brake pad composites resulted in a more stable friction coefficient. A similar result has been observed in the previous study [31] that 2 vol.\% h-BN with graphite in $\mathrm{Cu}-$ based friction composite can stabilize friction coefficient and wear resistance. h-BN could contribute to attenuating the effect of varying temperatures on frictional behavior.

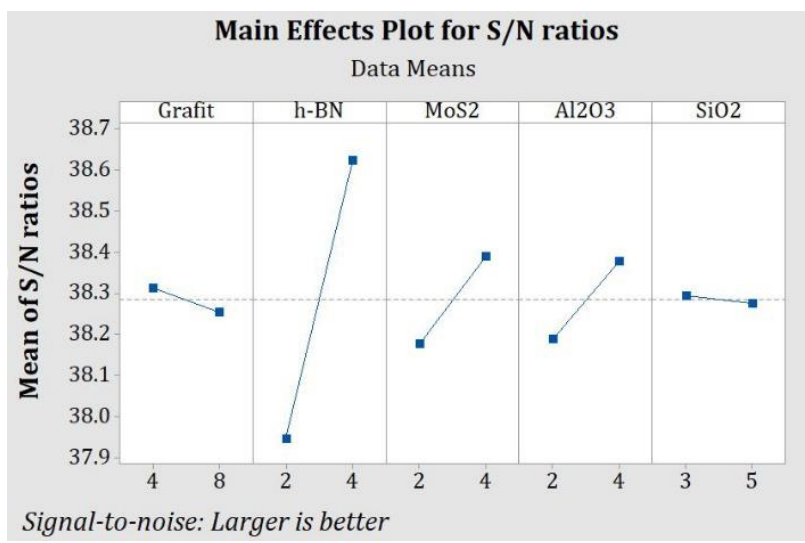

Fig. 3. Main effects plot for $\mathrm{S} / \mathrm{N}$ ratios of CoF stability of friction modifiers.

$\mathrm{MoS}_{2}$ and $\mathrm{Al}_{2} \mathrm{O}_{3}$ have more effect on the CoF stability compared to graphite and $\mathrm{SiO}_{2}$. $\mathrm{MoS}_{2}$ has self-lubricating capabilities, and it can prevent the wear debris from sticking to the disc surface. $\mathrm{MoS}_{2}$ prevents the formation of heterogeneous transfer films, leading to instability in the friction coefficient [21,32]. On the other hand, the addition of $\mathrm{Al}_{2} \mathrm{O}_{3}$ in the friction material causes the sample to be less sensitive to temperature increases during sliding. Thus, it resulted in a stable friction coefficient [33]. Singh et al. [34] reported that the presence of 5 wt. $\% \mathrm{Al}_{2} \mathrm{O}_{3}$ in non-asbestos brake composite resulted in the highest friction stability (0.87) and friction variability (0.48). It is due to $\mathrm{Al}_{2} \mathrm{O}_{3}$ as an abrasive, which can remove pyrolysis (unwanted coating) and renews the damaged (degraded) friction surface. Therefore, it can increase the integrity of friction film and friction stability [16].

Graphite and $\mathrm{SiO}_{2}$ at low factor levels (4 vol.\% graphite and 3 vol. $\% \mathrm{SiO}_{2}$ ) have an insignificant effect on the CoF stability. The low content of graphite in the friction material causes the occurrence of adhesion. It prevents the formation of the friction layer since only a few graphites may be distributed on the friction surface [35]. Thereby, the low content of graphite increases the roughness of the surface 
and instability of the friction coefficient. Meanwhile, $\mathrm{SiO}_{2}$ has an insignificant influence on the optimum friction coefficient due to its abrasive nature that causes pits formation on the wear surface. Pits formation on the wear surface increases the rough surface, friction fluctuation, and higher wear rate [34].

Table 5 shows the ANOVA analysis results for the $\mathrm{S} / \mathrm{N}$ ratio of CoF stability. The ANOVA analysis is evaluated for a confidence level of $95 \%(\alpha=0.05)$. A P-value less than 0.05 is considered to have a statistically significant contribution to the response parameter. In contrast, a P-value of more than 0.05 shows an insignificant contribution to response. The percentage contribution of $\mathrm{P}$ is calculated by equation (4).

$$
\begin{aligned}
& \% \text { contribution } \\
& =\frac{\text { Seq } S S_{\text {factor }}}{\text { Seq } S S_{\text {total }}} \times 100 \%
\end{aligned}
$$

Table 5. ANOVA for $\mathrm{S} / \mathrm{N}$ ratio of CoF stability (DF: Degree of freedom, Seq SS: Sum of squares, Adj MS: Adjusted mean of squares, F: ratio, P: value, Cont: Contribution).

\begin{tabular}{|c|c|c|c|c|c|c|}
\hline Source & DF & $\begin{array}{c}\text { Seq } \\
\text { SS }\end{array}$ & $\begin{array}{c}\text { Adj } \\
\text { MS }\end{array}$ & F & P & $\begin{array}{c}\text { Cont } \\
\text { (\%) }\end{array}$ \\
\hline Graphite & 1 & 0.007 & 0,007 & 0.09 & 0.798 & 0.57 \\
\hline $\mathrm{h}-\mathrm{BN}$ & 1 & 0.913 & 0.912 & 10.98 & 0.048 & 73.16 \\
\hline $\mathrm{MoS}_{2}$ & 1 & 0.089 & 0.089 & 1.070 & 0.409 & 7.14 \\
\hline $\mathrm{Al}_{2} \mathrm{O}_{3}$ & 1 & 0.072 & 0.071 & 0.860 & 0.451 & 5.76 \\
\hline $\mathrm{SiO}_{2}$ & 1 & 0.000 & 0.000 & 0.01 & 0.935 & 0.06 \\
\hline Error & 2 & 0.166 & 0.083 & & & 13.32 \\
\hline Total & 7 & 1.247 & & & & 100 \\
\hline
\end{tabular}

As shown in Table 5, the controllable factor of $\mathrm{h}$ $\mathrm{BN}$ is found to be significant ( $\mathrm{p}$-value $<0.05)$ and other factors insignificant ( $p$-value $>0.05$ ) for the CoF stability at 95\% confidence level. The contribution percentage of each factor is h-BN (73,16\%), $\mathrm{MoS}_{2}(7,14), \mathrm{Al}_{2} \mathrm{O}_{3}$ (5.76), graphite (0.57), and $\mathrm{SiO}_{2}(0.06 \%)$.

\section{$3.2 \mathrm{~S} / \mathrm{N}$ ratio and ANOVA for wear}

The brake pad wear should be as low as possible because it increases the brake pad's service life. The concept of "the lower the better" was used to calculate the $\mathrm{S} / \mathrm{N}$ ratio of wear quality characteristics. The $\mathrm{S} / \mathrm{N}$ ratio of wear is calculated by equation (5).

$$
\frac{S}{N} \text { ratio }=-10 \log \left(\frac{1}{n} \sum_{i=1}^{n} y_{i}^{2}\right)
$$

Where $y_{i}=$ experimental results, and $n=$ number of experiments. Table 6 shows the $\mathrm{S} / \mathrm{N}$ ratio of wear for friction modifiers. As shown in Table 6, $\mathrm{h}$-BN has the most effect on low wear, followed by graphite, $\mathrm{SiO}_{2}$, and $\mathrm{MoS}_{2}$. Meanwhile, $\mathrm{Al}_{2} \mathrm{O}_{3}$ has a much lower effect on low wear.

Table 6. Responsible table for $\mathrm{S} / \mathrm{N}$ ratio of wear of friction modifiers (the lower the better).

\begin{tabular}{|c|c|c|c|c|c|}
\hline Level & Graphite & h-BN & $\mathbf{M o S}_{\mathbf{2}}$ & $\mathbf{A l}_{\mathbf{2}} \mathbf{O}_{\mathbf{3}}$ & $\mathbf{S i O}_{\mathbf{2}}$ \\
\hline 1 & -20.48 & $-17,06$ & 19,22 & $-18,75$ & $-18,35$ \\
\hline 2 & $-17,20$ & $-20,62$ & 18,46 & $-18,93$ & $-19,32$ \\
\hline Delta & 3,28 & 3,56 & 0,76 & 0,18 & 0,97 \\
\hline Rank & 2 & 1 & 4 & 5 & 3 \\
\hline
\end{tabular}

Fig. 4 represents the main effect plot for the $\mathrm{S} / \mathrm{N}$ ratio on the wear of friction modifiers. Wear decreases with an increasing composition of graphite and $\mathrm{MoS}_{2}$ and decreasing composition of h-BN, $\mathrm{SiO}_{2}$, and $\mathrm{Al}_{2} \mathrm{O}_{3}$. Similar results were observed in the previous study [31]. The author reported that the content of 2 vol.\% h-BN and 8 vol.\% graphite in $\mathrm{Cu}$-based composite resulted in friction stability and wear rate.

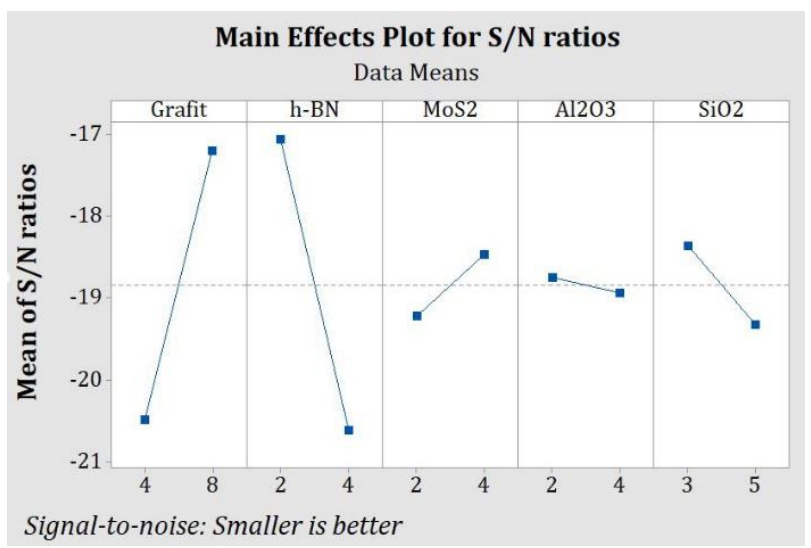

Fig. 4. Main effects plot for $\mathrm{S} / \mathrm{N}$ ratios of wear of friction modifiers.

The $\mathrm{h}-\mathrm{BN}$ has the most influence on minimum wear. This finding is attributed to the fact that h-BN can be used as a lubricant to optimizes friction reduction over a wide range of temperatures [19]. Graphite also shows a dominant influence on low wear after h-BN. The increase of graphite content on the friction material causes more graphite to be distributed on the friction surface. This condition can prevent adhesion and contribute to forming a 
friction layer on the friction interface [36-37]. The friction layers prevent the hard particles from sticking in the friction interface [35] and inhibit the micro-welding of metallic ingredients [38], thereby protecting the surface from excessive wear $[12,39]$. In the previous studies, the increase in graphite content $(0-10 \mathrm{vol} . \%)$ in friction composite significantly reduces wear rates [31]. Yang et al. [35] also reported that graphite enhancement (2.5 -10 wt.\%) could reduce the average friction coefficient, friction fluctuation, and wear rate.

The minimum wear for the vol.\% contribution is obtained on h-BN ( 2 vol.\%), graphite (8 vol.\%), $\mathrm{SiO}_{2}$ (3 vol.\%), $\mathrm{MoS}_{2}$ (4 vol.\%), and $\mathrm{Al}_{2} \mathrm{O}_{3}$ (2 vol. \%).

Table 7. ANOVA for S/N ratio of wear (DF: Degree of freedom, Seq SS: Sum of squares, Adj MS: Adjusted mean of squares, F: ratio, P: value, Cont: Contribution).

\begin{tabular}{|c|c|c|c|c|c|c|}
\hline Source & $\begin{array}{c}\text { D } \\
\text { F }\end{array}$ & Seq SS & $\begin{array}{c}\text { Adj } \\
\text { MS }\end{array}$ & F & P & $\begin{array}{c}\text { Cont } \\
\text { (\%) }\end{array}$ \\
\hline Graphite & 1 & 21.574 & 21.574 & 4.32 & 0.173 & 35.96 \\
\hline $\mathrm{h}-\mathrm{BN}$ & 1 & 25,344 & 25.344 & 5.08 & 0.153 & 42.24 \\
\hline $\mathrm{MoS}_{2}$ & 1 & 1.141 & 1.141 & 0.23 & 0.680 & 1.90 \\
\hline $\mathrm{Al}_{2} \mathrm{O}_{3}$ & 1 & 0.066 & 0.065 & 0.01 & 0.919 & 0.11 \\
\hline $\mathrm{SiO}_{2}$ & 1 & 1.885 & 1.884 & 0.38 & 0.602 & 3.14 \\
\hline Error & 2 & 9.985 & 4.992 & & & 16.64 \\
\hline Total & 7 & 59.994 & & & & \\
\hline
\end{tabular}

Table 7 exhibits the ANOVA analysis results for the $\mathrm{S} / \mathrm{N}$ ratio of wear. It is clearly seen that all of the controllable factors have an insignificant effect at a 95\% confidence level ( $p$-value $>0.05$ ) on the minimum wear of friction modifiers. The contribution percentage of $\mathrm{h}-\mathrm{BN}(42.24 \%)$ is more influential than graphite $(35.96 \%)$. The contribution percentages of $\mathrm{MoS}_{2}, \mathrm{Al}_{2} \mathrm{O}_{3}$, and $\mathrm{SiO}_{2}$ on wear are $1.90 \%, 0.11 \%$, and $3.14 \%$, respectively.

\subsection{Confirmation test within confidence interval $(95 \% \mathrm{CI})$}

The confirmation test is a crucial step to verify the results from the Taguchi design. In this study, the confirmation test was utilized on the optimal level of all the controllable factors. Three samples were then prepared under the optimal levels of $\mathrm{CoF}$ stability and wear. The optimum level of CoF stability is performed on graphite (4 vol.\%), h-BN (4 vol.\%), $\mathrm{MoS}_{2}$ (4 vol.\%), $\mathrm{Al}_{2} \mathrm{O}_{3}$ (4 vol.\%), and $\mathrm{SiO}_{2}$ (3 vol.\%). Meanwhile, the optimal level of wear is carried out on the composition of 8 vol.\% graphite, 2 vol.\% h-BN, 4 vol. $\% \mathrm{MoS}_{2}, 2$ vol. $\% \mathrm{Al}_{2} \mathrm{O}_{3}$, and 3 vol. $\% \mathrm{SiO}_{2}$. Table 8 represents the confirmation test results on the optimal level.

Table 8. Confirmation test results on the optimal level.

\begin{tabular}{|c|c|c|c|c|}
\hline \multirow{2}{*}{ Variable } & \multicolumn{3}{|c|}{ Sample } & \multirow{2}{*}{ Average } \\
\cline { 2 - 5 } & $\mathbf{1}$ & $\mathbf{2}$ & $\mathbf{3}$ & \\
\hline CoF stability & 88.431 & 89.25 & 91.552 & 89.738 \\
\hline Wear (\%) & 5.276 & 4.767 & 6.038 & 5.36 \\
\hline
\end{tabular}

The predictive value of the optimal level can be calculated by the Taguchi method, and this value is consistent with the confirmation test. The confidence interval (CI) is used for the confirmation test [23] and calculated by equation (6).

$$
C I= \pm \sqrt{\frac{F\left(1, n_{2}\right) \times M S_{e}}{N_{e}}}
$$

Where $\mathrm{F}\left(1, \mathrm{n}_{2}\right)$ is $\mathrm{F}$-table value on confidence level desired, MSe is the sum of the mean squared error calculated in the ANOVA table of $\mathrm{S} / \mathrm{N}$ ratio/mean. $\mathrm{Ne}$ is an effective number of replications. $\mathrm{Ne}$ is calculated by equation (7).

$$
\begin{aligned}
& \text { Ne } \\
& =\frac{\text { Total number of experiment }}{1+\text { DoF all factors in estimate of mean }}
\end{aligned}
$$

Table 9 represents the predictive value results (95\% CI) for the S/N ratio on the optimal level of CoF stability and wear. From these results, the following equation model can be drawn:

Table 9. Predictive value ( $95 \% \mathrm{CI}$ ) for $\mathrm{S} / \mathrm{N}$ ratio on the optimal level.

\begin{tabular}{|c|c|c|c|c|c|}
\hline Variable & $\begin{array}{c}\text { Predicted } \\
\text { value (S/N } \\
\text { ratio) }\end{array}$ & $\mathbf{F ( 1 , n 2 ) ~}$ & MSe & Ne & $\begin{array}{c}\mathbf{9 5 \%} \\
\mathbf{C I}\end{array}$ \\
\hline $\begin{array}{c}\text { CoF } \\
\text { stability }\end{array}$ & 38.854 & 13.01 & 0.166 & 2.667 & $\begin{array}{c} \pm \\
0.899\end{array}$ \\
\hline Wear & 19.176 & 10.02 & 9.985 & 2.667 & $\begin{array}{c} \pm \\
6.125\end{array}$ \\
\hline
\end{tabular}

Predicted value $-\mathrm{CI} \leq$ predicted value $\leq$ predicted value + CI

Therefore, the equation model of the $\mathrm{S} / \mathrm{N}$ ratio prediction on the optimal level is

$37.955 \leq 38.854 \leq 39.753$ for CoF stability, and $13.051 \leq 19.176 \leq 25.301$ for wear 
Table 10. Predictive value (95\% CI) for CoF stability and wear on the optimal level.

\begin{tabular}{|c|c|c|c|c|c|}
\hline Variable & $\begin{array}{c}\text { Predicted } \\
\text { value } \\
\text { (mean) }\end{array}$ & F(1,n2) & MSe & Ne & $\begin{array}{c}\mathbf{9 5 \%} \\
\text { CI }\end{array}$ \\
\hline $\begin{array}{c}\text { CoF } \\
\text { stability }\end{array}$ & 87.660 & 12.79 & 7.654 & 2.667 & $\begin{array}{c} \pm \\
6.058\end{array}$ \\
\hline Wear & 6.025 & 6.55 & 8.578 & 2.667 & $\begin{array}{c} \pm \\
4.589\end{array}$ \\
\hline
\end{tabular}

Table 10 shows the predictive value results $(95 \%$ CI) for CoF stability and wear on the optimal level. Consequently, the equation model below may be formulated:

Predicted value $-\mathrm{CI} \leq$ predicted value $\leq$ predicted value + CI .

The equation model for mean prediction value on the optimal level is

\section{$81.602 \leq 87.660 \leq 93.718$ for CoF stability, and} $1.436 \leq 6.025 \leq 10.614$ for wear

Based on the above results, the Taguchi method's predictive value is consistent with the confirmation test. On the optimal level, the predictive value and confirmation test results of the CoF stability and wear are presented in Figs. 5 and 6.

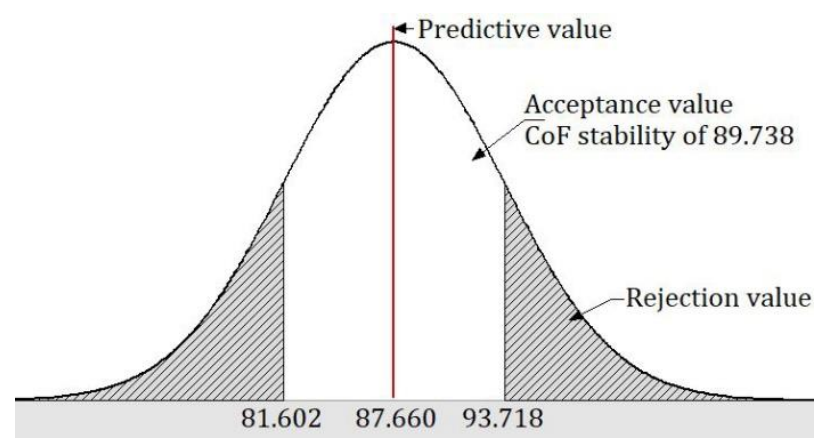

Fig. 5. Mean interval of CoF stability within 95\% CI.

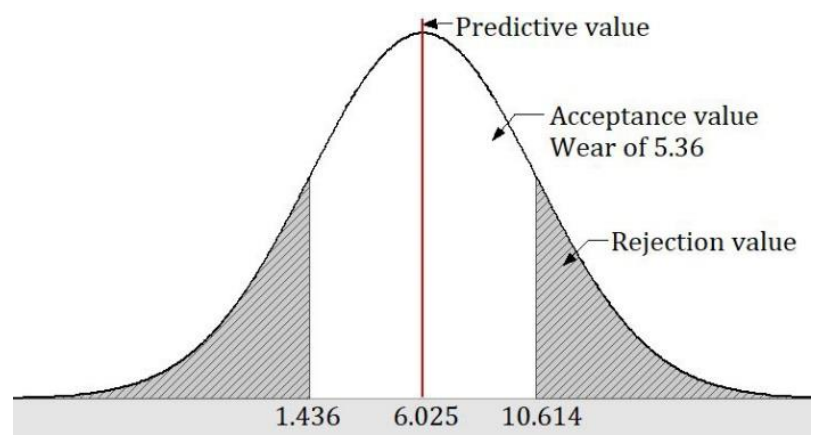

Fig. 6. Mean interval of wear within 95\% CI.

\subsection{Morphology of worn surface}

SEM image reveals the different characteristics of secondary/primary contact plateau, adhesive pits, wear debris, and microcracks related to the wear mechanism during the tribological test. SEM images and EDS analysis of the sample for CoF stability and wear on the optimal level are presented in Figs. 7 and 8. Figure 7a exhibits the worn surface of the sample for the optimal level of CoF stability. It is seen that the worn surface is relatively rougher. Besides, the secondary plateau, adhesive pits, microcracks, wear debris, and the agglomeration of graphite/hBN are also observed. The secondary plateau is formed by layers adhered [40] and finer debris compacted to the surface under shear force, normal force, and heat friction, simultaneously [41]. Meanwhile, the formation of microcracks is a result of thermal shock stress [42]. The sample surface is subjected to force and friction heat, which generated an unstable temperature and force. Thus, there is a difference in expansion heat in some areas of the friction interface, resulting in microcracks on the worn surface (Fig. 7a). Microcracks is a type of fatigue wear [4]. Meanwhile, adhesive pits are formed on the worn surface due to shearing force, indicating adhesive wear has occurred. Therefore, the sample wear mechanism is abrasive wear, adhesive wear, and fatigue wear. From the EDS analysis as shown in Fig. $7 \mathrm{~b}$, elements were detected on the worn surface, namely: carbon (C), nitrogen $(\mathrm{N})$, oxygen $(\mathrm{O})$, magnesium $(\mathrm{Mg})$, aluminum (Al), silicon (Si), iron (Fe), molybdenum (Mo), calcium $(\mathrm{Ca})$, and copper $(\mathrm{Cu})$. These elements are originated from the sample ingredients. The higher concentration of elements on the worn surface is found on the elements of $\mathrm{C}$ (30.83\%), O (28.93\%), N (9.32\%), and Fe (13.83\%). C and $\mathrm{O}$ elements at a higher level indicate oxidation on the sample, which might occur from the thermal oxidation of organic and inorganic ingredients as graphite and $\mathrm{MoS}_{2}$. In previous studies, graphite decomposed into the gas at elevated temperature [35]. Whereas, $\mathrm{MoS}_{2}$ reacted with oxygen and transformed into oxide form $\left(\mathrm{MoO}_{3}\right)$ at $540{ }^{\circ} \mathrm{C}[22,43]$. Fe element detected on the worn surface is possibly transferred from friction drum (cast iron) due to thermal-oxidation during friction test. The thermal oxidation on the disc surface causes film transfer (containing $\mathrm{Fe}_{2} \mathrm{O}_{3}$ ) to the sample surface. This finding is in line with previous studies $[27,44,45]$. 


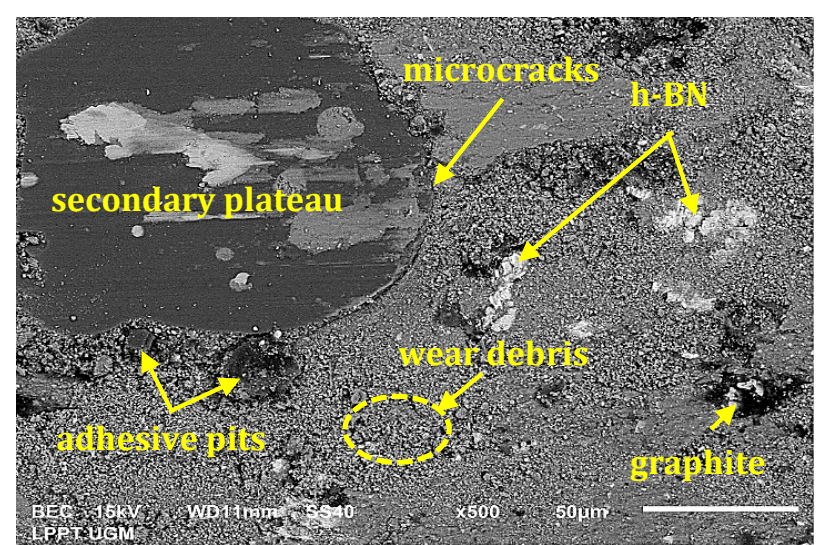

(a)

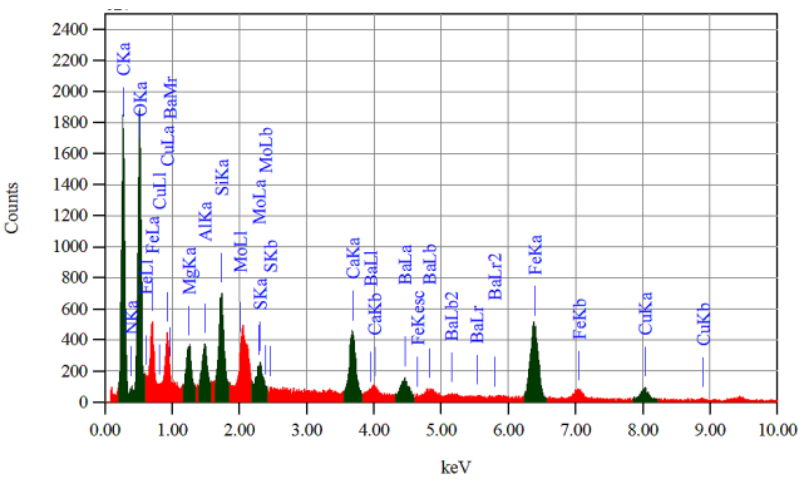

(b)

Fig. 7. Sample on the optimal level of CoF stability (a) worn surface morphology, and (b) EDS analysis.

Figure 8a shows the worn surface sample for the optimal level of wear. The worn surface is relatively smooth and visibly covered by a secondary plateau. Meanwhile, microcracks, wear debris, adhesive pits, primary plateau, graphite, and h-BN are also revealed on the worn surface. Primary plateau is formed from fiber trapped in the friction interface under shearing force. Figure $8 \mathrm{~b}$ represents the EDS analysis, the area of worn surface is composed of some elements, including carbon (C), oxygen (O), nitrogen $(\mathrm{N})$, iron $(\mathrm{Fe})$, molybdenum (Mo), silicon $(\mathrm{Si})$, aluminum ( $\mathrm{Al})$, magnesium $(\mathrm{Mg})$, calcium (Ca), and copper $(\mathrm{Cu})$. The higher concentration is found in the element of C (32.14\%), 0 (28.95\%), and $\mathrm{N}(11.97 \%)$, while lower concentration is obtained on the element of $\mathrm{Al}$ (1.74\%), Si (4.29\%), Fe (3.13\%), and Mo (1.07\%). These results indicate that the worn surface was dominated by compacted wear debris containing $\mathrm{C}, \mathrm{O}$, and $\mathrm{N}$ elements. These elements originated from the ingredients sample and oxidation, i.e., graphite, h-BN, $\mathrm{MoS}_{2}, \mathrm{Al}_{2} \mathrm{O}_{3}$, and $\mathrm{SiO}_{2}$. The wear debris containing many $\mathrm{C}$-elements promotes a more extensive secondary plateau, which is responsible for improving wear resistance on the sample. Therefore, the mechanism wear of this sample is abrasive wear, adhesive wear, and fatigue wear.

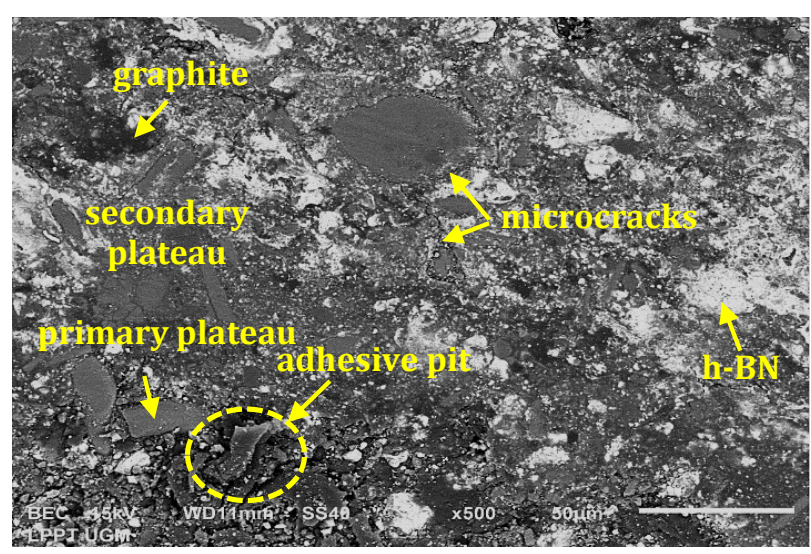

(a)

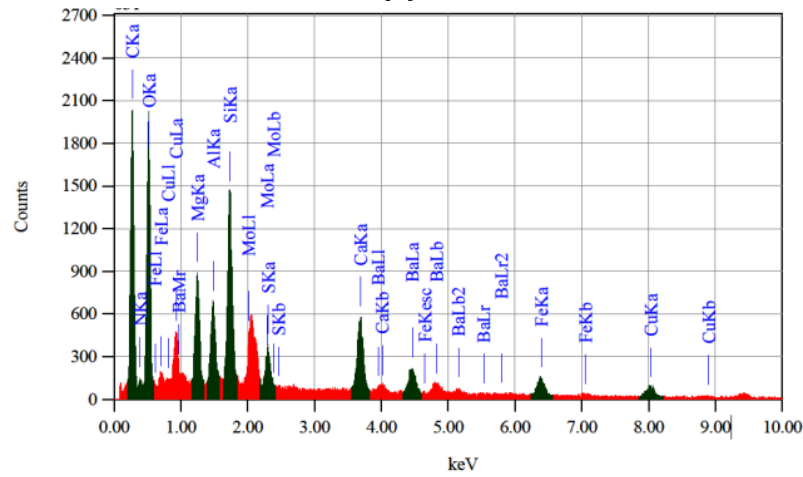

(b)

Fig. 8. Sample on the optimal level of wear (a)worn surface morphology, and (b) EDS analysis.

\section{CONCLUSIONS}

This experiment study determines the optimal level of friction modifiers on the tribological properties of non-asbestos organic brake pad using the Taguchi method. The results are summarized as follows:

1. The controllable factor of $h-B N$ has a significant effect on the high CoF stability; while graphite, $\mathrm{MoS}_{2}, \mathrm{Al}_{2} \mathrm{O}_{3}$, and $\mathrm{SiO}_{2}$ are unsignificant. Contribution of 4 vol.\% h-BN, 4 vol.\% graphite, 4 vol. $\% \mathrm{MoS}_{2}$, 4 vol. $\% \mathrm{Al}_{2} \mathrm{O}_{3}$, and 3 vol. $\% \mathrm{SiO}_{2}$ can be an optimal composition of friction modifiers in non-asbestos organic (NAO) brake pad material to obtain a high CoF stability.

2. The controllable factor of h-BN and graphite have the most influence on lower wear. On the other hand, the effect of $\mathrm{MoS}_{2}, \mathrm{Al}_{2} \mathrm{O}_{3}$, and $\mathrm{SiO}_{2}$ is lower. Contribution of 8 vol.\% graphite, 2 vol. $\%$ h-BN, 4 vol. $\% \mathrm{MoS}_{2}$, 2 vol. $\% \mathrm{Al}_{2} \mathrm{O}_{3}$, and 3 vol.\% $\mathrm{SiO}_{2}$ is an optimal level of friction modifiers to obtain a low wear. 
3. The CoF stability and wear predicted value by utilizing the optimal level of the Taguchi optimization method is consistent with the confirmation test (CoF stability mean value of 89.738 and wear is 5.36\%) within the 95\% confidence interval (CI).

\section{Acknowledgement}

This research is funded by the Indonesian Ministry of Finance through Lembaga Pengelola Dana Pendidikan (LPDP)

\section{REFERENCES}

[1] G. Akıncıoğlu, S. Akıncıoğlu, H. Öktem, İ. Uygur, Experimental Investigation on The Friction Characteristics of Hazelnut Powder Reinforced Brake Pad, Report in Mechanical Engineering, vol. 2, iss. 1, pp. 23-30, 2021, doi: 10.31181/rme200102023a

[2] H. Öktem, I. Uygur, G. Akıncioğlu, A. Kurt, Experimental Study on the Performance Characteristics of Non-asbestos Brake Pads Using a Novel Friction Testing Machine, Experimental Technique, Online first articles, 2021, doi: 10.1007/s40799-020-00416-2

[3] H. Yanar, H. Ayar, M. Demirtas, G. Purcek, Effect of Resin Content on Tribological Behavior of Brake Pad Composite Material, Industrial Lubrication and Tribology, vol. 72, iss. 2, pp. 195-202, 2018, doi: 10.1108/ILT-05-2018-0171

[4] Y. Liu, L. Wang, D. Liu, Y. Ma, Y. Tian, J. Tong, Evaluation of Wear Resistance of Corn Stalk Fiber Reinforced Brake Friction Materials Prepared by Wet Granulation, Wear, vol. 432-433, 2019, pp. 1-9, 2019, doi: 10.1016/j.wear.2019.05.033

[5] Y. Liu, Y. Ma, X. Lv, J. Yu, J. Zhuang, J. Tong, Mineral Fibre Reinforced Friction Composites: Effect of Rockwool Fibre on Mechanical and Tribological Behaviour, Materials Research Express, vol. 5, iss. 9, pp. 573-584, 2018, doi: 10.1088/20531591/aad767

[6] D.L. Singaravelu, R. Vijay, P. Filip, Influence of Various Cashew Friction Dusts on the Fade and Recovery Characteristics of Non-asbestos Copper Free Brake Friction Composites, Wear, vol. 426-427, pp. 1129-1141, 2019, doi: 10.1016/j.wear.2018.12.036

[7] R.M.S.B. Surya Rajan, M.A. Saibalaji, Tribological Performance Evaluation of Epoxy Modified Phenolic FC reinforced with Chemically Modified Prosopis Juliflora Bark Fiber, Materials Research
Express, vol. 6, iss. 7, pp. 1-26, 2019, doi: 10.1088/2053-1591/ab07e6

[8] D. Chan, G.W. Stachowiak, Review of Automotive Brake Friction Materials, Proceedings of the Institution of Mechanical Engineers, vol. 218, iss. 9, pp. 953-966, 2004, doi: $10.1243 / 0954407041856773$

[9] J. Bijwe, N. Aranganathan, S. Sharma, N. Dureja, R. Kumar, Nano-Abrasives in Friction MaterialsInfluence on Tribological Properties, Wear, vol. 296, iss. 1-2, pp. 693-701, 2012, doi: 10.1016/j.wear.2012.07.023

[10] Y. Lu, L. Jiao, L. Huang, Effects of Silicon Carbide Particle Sizes on Friction-Wear Properties of Friction Composites Designed for Car Brake Lining Applications, Tribology International, vol. 43, iss. $1-2$ pp. 144-151, 2010, doi: 10.1016/j.triboint.2009.05.007

[11] J. Echeberria, Influence of Abrasives and Graphite on processing and properties of sintered metallic friction materials, Heliyon, vol. 5, iss. 8, pp. 1-12, 2019, doi: 10.1016/j.heliyon.2019.e02311

[12] W. Österle, A.I. Dmitriev, The Role of Solid Lubricants for Brake Friction Materials, Lubricants, vol. 4, iss. 1, pp. 1-22, 2016, doi: 10.3390/lubricants4010005

[13] M. Vala, Effects of $\mathrm{ZrSiO}_{4}$ in Non-Metallic Brake Friction Materials on Friction Performance, Tribology International, vol. 41, iss. 3, pp. 166174, 2008, doi: 10.1016/j.triboint.2007.07.004

[14] M. Boz, A. Kurt, The Effect of $\mathrm{Al}_{2} \mathrm{O}_{3}$ on the Friction Performance of Automotive Brake Friction Materials, Tribology International, vol. 40, iss. 7, pp. 1161-1169, 2007, doi: 10.1016/j.triboint.2006.12.004

[15] R. Yun, Y. Lu, Effects of Alumina in Nonmetallic Brake Friction Materials on Friction Performance, Journal of Materials Science, vol. 44, pp. 266-273, 2009, doi: 10.1007/s10853-008-3041-z

[16] Y. Fan, V. Mat, G. Kratošová, Y. Lu, Role of $\mathrm{Al}_{2} \mathrm{O}_{3}$ in Semi-Metallic Friction Materials and its Effects on Friction and Wear Performance, Tribology Transactions, vol. 51, iss. 6, pp. 771-778, 2008, doi: 10.1080/10402000802011760

[17] W. Sun, W. Zhou, J. Liu, X. Fu, G. Chen, S. Yao, The Size Effect of $\mathrm{SiO}_{2}$ Particles on Friction Mechanisms of a Composite Friction Material, Tribology Letters, vol. 66, iss. 35, pp. 1-10, 2018, doi: 10.1007/s11249-018-0987-0

[18] O.N. Celik, N. AY, Y. Goncu, Effect of Nano Hexagonal Boron Nitride Lubricant Additives on the Friction and Wear Properties of AISI 4140 Steel, Particulate Science and Technology, vol. 31, iss. 5, pp. 501-502, 2013, doi: 10.1080/02726351.2013.779336 
[19] S. Mahathanabodee, T. Palathai, S. Raadnui, R. Tongsri, N. Sombatsompop, Effects of Hexagonal Boron Nitride and Sintering Temperature on Mechanical and Tribological Properties of SS316L/hBN composites, Materials and Design, vol. 46, pp. 588-597, 2013, doi: 10.1016/j.matdes.2012.11.038

[20] K. Sathickbasha, A.S. Selvakumar, M.A.S. Balaji, B S. Rajan, The Dual Role of Metal Sulfides as Lubricant and Abrasive: An Interface Study in Friction Composite, Materials Research Express, vol. 6, iss. 4, pp. 1-20, 2019, doi: 10.1088/2053-1591/aafd5a

[21] H.B.C. Jeong Hee Kim, J. Geun Choi, H. Rae Kim, Effect of $\mathrm{MoS}_{2}$ on Transfer Film Formation and Friction Coefficients in NAO Friction Material, Industrial Lubrication Tribology, vol. 72, iss. 2, pp. 221-231, 2019, doi: 10.1108/ILT-07-2017-0209

[22] S.M.R. Vijay, D.L. Singaravelu, M. Kchaou, Experimental Investigation on the Tribo-Thermal Properties of Brake Friction Materials Containing Various Forms of Graphite : A Comparative Study, Arabian Journal of Science Engineering, vol. 44, pp. 1459-1473, 2019, doi: 10.1007/s13369018-3590-7

[23] R.K. Roy, A Primer on the Taguchi Method, Society of Manufacturing Engineers, 2010.

[24] F. Yudhanto, Jamasri, H.S.B. Rochardjo, Application of Taguchi Method for Selection Parameter Bleaching Treatments Against Mechanical and Physical Properties of Agave Cantala Fiber, IOP conference Series: Materials Science and Engineering, vol. 352, 2018, doi: 10.1088/1757-899X/352/1/012002

[25] M.A. Chowdhury, U.K. Debnath, D.M. Nuruzzaman, S. Mia, Analysis and Optimization of Turned Surfaces of AISI 1060 using ANOVA and Regression, Tribology in Industry, vol. 14, no. 1, pp 23-32, 2019, doi: 10.24874/ti.2019.41.01.03

[26] P. Nawangsari, Jamasri, H.S.B. Rochardjo, A.T. Waskito, $\mathrm{BaSO}_{4}$-Friction Dust Filler Improves Friction Characteristic in Non-Asbestos Brake Pad Composite, International Review of Mechanical Engineering, vol. 13, iss. 9, pp. 513-522, 2019, doi: 10.15866/ireme.v13i9.17669

[27] P. Nawangsari, Jamasri. H.S.B. Rochardjo, A.T. Waskito, Optimization of the Ternary Combinations of Rockwool-PAN-Cellulose Fibers for the Best FadeRecovery Performance in Nonasbestos Organic Brake Pad Composite, International Journal of Automotive Engineering, vol. 11, iss. 2, pp. 64-74, 2020, doi: 10.20485/jsaeijae.11.2_64

[28] Y. Ma, Y. Liu, L. Wang, J. Tong, J. Zhuang, H. Jia, Performance Assessment of Hybrid Fibers Reinforced Friction Composites under Dry Sliding Conditions, Tribology International, vol. 119, pp. 262-269, 2018, doi: 10.1016/j.triboint.2017.11.012
[29] G. Yi, F. Yan, Effect of Hexagonal Boron Nitride and Calcined Petroleum Coke on Friction and Wear Behavior of Phenolic Resin-based Friction Composites, Material Science and Engineering: A, vol. 425, iss. 1-2, pp. 330-338, 2006, doi: 10.1016/j.msea.2006.03.101

[30] H. Yanar, H. Ayar, M. Demirtas, G. Purcek, Effect of Hexagonal Boron Nitride ( $h-B N$ ) Addition on the Friction and Wear Characteristics of Non-asbestos Composites Used in Brake Pads, in IX Iberian Conference on Tribology, 12-13 June, 2017, University of Minho, Guimarães, Portugal, pp. 3-4.

[31] B. Chen, Q. Bi, J. Yang, Y. Xia, J. Hao, Tribological properties of solid lubricants (graphite, $h$-BN) for Cu-based P/M Friction Composites, Tribology International, vol. 41, iss. 12, pp. 1145-1152, 2008, doi: 10.1016/j.triboint.2008.02.014

[32] C. Gao, L. Bredell, D. Kuhhnann-wilsdorf, D.D. Makel, Micromechanics of $\mathrm{MoS}_{2}$ Lubrication, Wear, vol. 162-164, pp. 480-491, 1993, doi: 10.1016/0043-1648(93)90533-R

[33] P. Taylor, Y. Fan, V. Mat, G. Kratošová, Y. Lu, Role of $\mathrm{Al}_{2} \mathrm{O}_{3}$ in Semi-Metallic Friction Materials and its Effects on Friction and Wear Performance Role of $\mathrm{Al}_{2} \mathrm{O}_{3}$ in Semi-Metallic Friction Materials and its Effects on Friction and Wear Performance, Tribology Transactions, vol. 51, iss. 6, pp. 771778, 2008, doi: 10.1080/10402000802011760

[34] T. Singh, A. Patnaik, R. Chauhan, I. Bíró, E. Jánosi, G. Fekete, Performance Assessment of Phenolicbased Non-Asbestos Organic Brake Friction Composite Materials with Different Abrasives, Acta Polytech Hungaria, vol. 17, no. 5, pp. 49-67, 2020, doi: 10.12700/APH.17.5.2020.5.3

[35] Z. Yang, Y. Ge, X. Zhang, B. Shangguan, Y. Zhang, J. Zhang, Effect of Carbon Content on Friction and Wear Properties of Copper Matrix Composites at High Speed Current-Carrying, Materials, vol. 12, iss. 18, pp. 1-13, 2019, doi: 10.3390/ma12182881

[36] Jamasri, V. Malau, M.N. Ilman, E. Surojo, Evaluation of Ingredient Effects on Friction Brake Shoe Composite Using Taguchi Method, Journal of Surface Science and Technology, vol. 30, iss. 3-4, pp. 111-128, 2014.

[37] E. Surojo, Jamasri, V. Malau, M.N. Ilman, Characteristic Evaluation of Brake Block Material, Tribology in Industry, vol. 39, iss. 4, pp. 527-535, 2017, doi: 10.24874/ti.2017.39.04.12

[38] E. Surojo, Jamasri, V. Malau, M.N. Ilman, Investigation of Friction Behaviors of Brake Shoe Materials using Metallic Filler, Tribology in Industry, vol. 37, iss. 4, pp. 473-481, 2015.

[39] A.M. Martinez, J. Echeberria, Towards a Better Understanding of The Reaction between Metal 
Powders and the Solid Lubricant $\mathrm{Sb}_{2} \mathrm{~S}_{3}$ in a LowMetallic Brake Pad at High Temperature, Wear, vol. 348-349, pp. 27-42, 2016, doi: 10.1016/j.wear.2015.11.014

[40] G. Akıncioglu, H. Oktem, I. Uygur, S. Akincioglu, Determination of Friction-Wear Performance and Properties of Eco-Friendly Brake Pads Reinforced with Hazelnut Shell and Boron Dusts, Arabian Journal for Science and Engineering, vol. 43, pp. 4727-4737, 2018, doi: 10.1007/s13369-0183067-8

[41] J. Lee, J. Lee, S. Kwon, J. Kim, Effect of Different Reinforcement Materials on the Formation of Secondary Plateaus and Friction Properties in Friction Materials for Automobiles, Tribology International, vol. 120, pp. 70-79, 2018, doi:10.1016/j.triboint.2017.12.020

[42] W. Sun, W. Zhou, J. Liu, X. Fu, G. Chen, S. Yao, Development of a Composite Friction Material with Excellent Fade Resistance by Employing Oversized
Ceramic Particles, Tribology Letters, vol. 66, iss. 22, pp. 1-11, 2018, doi: 10.1007/s11249-017-0974-x

[43] T. Nadu, Influence of Molybdenum Disulfide Particle Size on Friction and Wear Characteristics of Non-asbestos-based Copper-free Brake Friction Composites, Surface Review Letter, vol. 27, no. 1, pp. 1-20, 2019, doi: 10.1142/S0218625X19500859

[44] H. Öktem, İ. Uygur, Wear Response of Nonasbestos Brake Pad Composites Reinforced with Walnut Shell Dust, Journal of the Australian Ceramic Society, vol. 56, pp. 1061-1072, 2020, doi: $10.1007 / s 41779-020-00452-6$

[45] G. Saikrishnan, Influence of Iron - Aluminum Alloy on the Tribological Performance of Non-asbestos Brake Friction Materials - a Solution for Copper Replacement, Industrial Lubrication and Tribology, vol. 72, iss. 1, pp. 66-78, 2019, doi: 10.1108/ILT-12-2018-0441 